\title{
Rhodobacter aestuarii sp. nov., a phototrophic alphaproteobacterium isolated from an estuarine environment
}

\author{
V. Venkata Ramana, ${ }^{1}$ P. Anil Kumar, ${ }^{2}$ T. N. R. Srinivas, ${ }^{2}$ Ch. Sasikala ${ }^{2}$ \\ and Ch. V. Ramana ${ }^{1}$ \\ ${ }^{1}$ Department of Plant Sciences, School of Life Sciences, University of Hyderabad, PO Central \\ University, Hyderabad 500 046, India \\ ${ }^{2}$ Bacterial Discovery Laboratory, Centre for Environment, Institute of Science and Technology, \\ JNT University, Kukatpally, Hyderabad 500 085, India
}

\begin{abstract}
An ovoid to rod-shaped, phototrophic, purple non-sulfur bacterium was isolated from a browncoloured microbial mat from the brackish water of Bhitarkanika mangrove forest, Dangmal, Orissa, India. Cells of strain JA296 ${ }^{\top}$ were Gram-negative and motile, forming chains of four to eight cells. The colour of the cell suspension grown under anaerobic conditions in the light was yellowish green. Bacteriochlorophyll $a$ and the carotenoids spheroidene and spheroidenone of the spirilloxanthin series were present as photosynthetic pigments. The bacterium was a facultative anaerobe and was able to grow photo-organoheterotrophically and chemoorganoheterotrophically. Thiamine was required as a growth factor. $\mathrm{C}_{18: 1} \omega 7 c$ was the dominant fatty acid. Internal cytoplasmic membranes were of the vesicular type. Strain JA296 ${ }^{\top}$ did not require $\mathrm{NaCl}$ for growth. Phylogenetic analysis on the basis of 16S rRNA gene sequences showed that strain $\mathrm{JA} 296^{\top}$ was most closely related to Rhodobacter capsulatus ATCC $11166^{\top}$ ( $95.5 \%$ sequence similarity) and clustered with species of the genus Rhodobacter of the family Rhodobacteraceae, class Alphaproteobacteria. On the basis of 16S rRNA gene sequence analysis and morphological and physiological characteristics, strain JA296 ${ }^{\top}$ represents a novel species of the genus Rhodobacter, for which the name Rhodobacter aestuarii sp. nov. is proposed; the type strain is $\mathrm{JA}^{296^{\top}}\left(=\mathrm{JCM} 14887^{\top}=\mathrm{CCUG}^{5} 5130^{\top}\right)$.
\end{abstract}

At the time of writing, the genus Rhodobacter comprised ten recognized species, including five species that have been described by our group: Rhodobacter vinaykumarii (Srinivas et al., 2007b), Rba. changlensis (Anil Kumar et al., 2007), Rba. ovatus (Srinivas et al., 2008), Rba. maris (Venkata Ramana et al., 2008) and Rba. megalophilus (Arunasri et al., 2008). Members of the genus Rhodobacter can be differentiated from those of other genera based primarily on internal cytoplasmic membranes, type of cytochromes, quinone components, lipopolysaccharides, $\mathrm{NaCl}$ requirement for optimal growth, 16S rRNA gene sequences and phenotypic characters (Imhoff, 2005). All species of the genus Rhodobacter except Rba. vinaykumarii and Rba. maris were described on the basis of freshwater isolates. Rba. vinaykumarii is a true marine species, requiring $\mathrm{NaCl}$ for growth, which necessitated emendation

The GenBank/EMBL/DDBJ accession number for the $16 \mathrm{~S}$ rRNA gene sequence of strain $\mathrm{JA}^{2} 26^{\top}$ is $\mathrm{AM} 748926$.

An electron micrograph of an ultrathin section of strain $\mathrm{JA} 296^{\top}$ and absorption spectra of pigments of strain $\mathrm{JA}^{2} 96^{\top}$ are available as supplementary material with the online version of this paper. of the genus description. Rba. maris, although isolated from marine waters, does not require $\mathrm{NaCl}$ for growth. During investigations of the purple bacterial diversity of brackish water, a purple non-sulfur bacterium (strain JA296 ${ }^{\mathrm{T}}$ ) was isolated from water of a mangrove forest. Although isolated from salty waters, strain JA296 ${ }^{\mathrm{T}}$ is a nonmarine isolate. On the basis of phenotypic and molecular analyses, it is proposed that strain JA296 ${ }^{\mathrm{T}}$ represents a novel species.

A brown-coloured microbial mat sample from the Bhitarkanika mangrove forest at Dangmal, Orissa, India (GPS position: $20^{\circ} 49^{\prime} \mathrm{N} 86^{\circ} 47^{\prime} \mathrm{E}$ ), was collected in a sterile glass bottle. Strain JA296 ${ }^{\mathrm{T}}$ was isolated from enrichments under photo-organoheterotrophic conditions. Purification and polyphasic taxonomic analyses were carried out as described previously (Srinivas et al., 2007a). Fatty acid methyl esters were prepared, separated and identified according to the instructions of the Microbial Identification System (Microbial ID, MIDI; Agilent 6850) (Sasser, 1990) at the Royal Research Laboratories, Secunderabad, India. 16S rRNA gene sequences were aligned 
Table 1. Differential characteristics of strain $\mathrm{JA} 296^{\top}$ and other species of the genus Rhodobacter

Strain/species: 1, Rhodobacter aestuarii sp. nov. JA296 ${ }^{\mathrm{T}}$; 2, Rba. capsulatus (data from Imhoff, 2005); 3, Rba. maris (Venkata Ramana et al., 2008); 4, Rba. veldkampii (Hansen \& Imhoff, 1985; Imhoff, 2005); 5, Rba. vinaykumarii (Srinivas et al., 2007b); 6, Rba. ovatus (Srinivas et al., 2008); 7, Rba. blasticus (Imhoff, 2005); 8, Rba. azotoformans (Hiraishi et al., 1996); 9, Rba. megalophilus (Arunasri et al., 2008); 10, Rba. sphaeroides (Imhoff, 2005); 11, Rba. changlensis (Anil Kumar et al., 2007). For all taxa, organic substrate utilization was tested during photo-organoheterotrophic growth. All taxa utilized pyruvate, but not benzoate or arginine. Motile species exhibit polar flagella. +, Substrate utilized or present; -, substrate not utilized or absent; \pm , variable in different strains; $(+)$, weak growth; NR, not reported.

\begin{tabular}{|c|c|c|c|c|c|c|c|c|c|c|c|}
\hline Characteristic & 1 & 2 & 3 & 4 & 5 & 6 & 7 & 8 & 9 & 10 & 11 \\
\hline Cell width $(\mu \mathrm{m})$ & $0.7-1.0$ & $0.5-1.2$ & $0.6-1.0$ & $0.6-0.8$ & $0.8-1.2$ & $0.9-1.2$ & $0.6-0.8$ & $0.6-1.0$ & $1.2-1.5$ & $2.0-2.5$ & $0.8-1.0$ \\
\hline Cell length $(\mu \mathrm{m})$ & $1.5-2.0$ & $2.0-2.5$ & $1.0-1.5$ & $1.0-1.3$ & $1.5-3.0$ & $1.0-2.0$ & $1.0-2.5$ & $0.9-1.5$ & $1.5-2.0$ & $2.5-3.5$ & $2.0-4.0$ \\
\hline Cell shape* & \multicolumn{3}{|c|}{ O to $\mathrm{R}, \mathrm{C} O$ to $\mathrm{R}, \mathrm{C} O$ to $\mathrm{R}, \mathrm{C}$} & O to $\mathrm{R}$ & $\mathrm{R}$ & $\mathrm{O}$ & O to $\mathrm{R}$ & O to $\mathrm{R}$ & $\mathrm{O}$ & $S$ to $\mathrm{O}$ & $\begin{array}{l}\text { O to } \mathrm{R}, \\
\mathrm{C}\end{array}$ \\
\hline Motility & + & + & + & - & - & - & - & + & - & + & - \\
\hline Colour of cell suspension $\dagger$ & ҮВ & ҮВ & YВ & ҮВ & YВ & YB & OB & YВ & YВ & GB & ҮВ \\
\hline $\begin{array}{l}\text { Internal membrane } \\
\text { system } \ddagger\end{array}$ & $\mathrm{v}$ & $\mathrm{v}$ & $\mathrm{V}$ & $\mathrm{v}$ & $\mathrm{v}$ & $\mathrm{V}$ & $\mathrm{L}$ & $\mathrm{V}$ & $\mathrm{v}$ & $\mathrm{v}$ & $\mathrm{v}$ \\
\hline Slime production & - & \pm & - & - & + & - & - & + & + & \pm & + \\
\hline $\mathrm{NaCl}$ required & - & $-\S$ & - & - & $+(1-4 \%)$ & - & - & -11 & - & -9 & - \\
\hline $\mathrm{pH}$ range & $6.0-8.5$ & $6.5-7.5$ & $5.0-8.0$ & NR & $6.0-8.0$ & $6.0-8.0$ & NR & $\mathrm{NR}$ & NR & $6.0-8.5$ & $6.5-8.0$ \\
\hline pH optimum & 7.0 & 7.0 & $6.5-7.0$ & 7.5 & $6.0-7.5$ & $6.5-7.0$ & $6.5-7.5$ & $7.0-7.5$ & NR & 7.0 & $6.5-7.5$ \\
\hline $\begin{array}{l}\text { Temperature optimum } \\
\left({ }^{\circ} \mathrm{C}\right)\end{array}$ & $25-30$ & $30-35$ & $25-30$ & $30-35$ & $20-30$ & $25-30$ & $30-35$ & $30-35$ & $5-40$ & $30-34$ & $20-30$ \\
\hline Sulfate assimilation & + & + & + & - & + & + & + & + & + & + & + \\
\hline Denitrification & - & - & - & - & - & - & - & + & NR & NR & - \\
\hline Vitamins required\# & $\mathrm{t}$ & $\mathrm{t}(\mathrm{b}, \mathrm{n})$ & $\mathrm{t}$ & $\mathrm{b}, p-\mathrm{ABA}, \mathrm{t}$ & $\mathrm{b}$ & $\mathrm{b}, \mathrm{t}$ & $\mathrm{b}, \mathrm{n}, \mathrm{t}, \mathrm{B}_{12}$ & $\mathrm{~b}, \mathrm{n}, \mathrm{t}$ & $\mathrm{t}$ & $\mathrm{b}, \mathrm{t}, \mathrm{n}$ & $\mathrm{b}, \mathrm{n}, \mathrm{t}$ \\
\hline $\begin{array}{l}\text { DNA G }+C \text { content } \\
(\mathrm{mol} \%)\end{array}$ & 65.1 & $68.1-69.6$ & 62.9 & $64.4-67.5$ & 68.8 & 70.1 & 65.3 & $69.5-70.2$ & 66.7 & $70.8-73.2$ & 69.4 \\
\hline \multicolumn{12}{|l|}{$\begin{array}{l}\text { Carbon source/electron } \\
\text { donor }\end{array}$} \\
\hline Hydrogen & - & + & - & - & - & - & + & NR & - & + & - \\
\hline Sulfide & - & + & - & + & - & - & - & + & - & + & - \\
\hline Thiosulfate & - & - & - & + & - & - & - & - & + & - & - \\
\hline Sulfur & - & - & - & + & - & - & - & - & NR & - & - \\
\hline Formate & - & + & - & - & - & - & - & + & + & - & - \\
\hline Acetate & - & + & $(+)$ & + & + & $(+)$ & + & + & + & + & - \\
\hline Propionate & - & + & $(+)$ & + & - & $(+)$ & + & + & + & + & - \\
\hline Butyrate & - & + & $(+)$ & + & $(+)$ & + & + & + & + & + & - \\
\hline Valerate & - & + & $(+)$ & + & - & + & NR & NR & + & + & - \\
\hline Caproate & - & + & $(+)$ & + & - & + & NR & $\mathrm{NR}$ & + & + & - \\
\hline Caprylate & - & + & - & + & - & - & NR & - & NR & + & - \\
\hline Tartrate & - & - & - & - & - & - & - & - & + & + & - \\
\hline Lactate & $(+)$ & + & $(+)$ & + & - & - & + & + & + & + & - \\
\hline Malate & - & + & + & + & - & - & + & + & + & + & - \\
\hline Fumarate & - & + & $(+)$ & + & - & - & + & + & + & + & - \\
\hline Citrate & - & \pm & - & - & - & - & + & $\mathrm{NR}$ & - & + & - \\
\hline Aspartate & - & \pm & - & + & - & - & NR & $\mathrm{NR}$ & + & NR & - \\
\hline Glutamate & - & + & - & + & + & - & + & + & + & + & + \\
\hline Gluconate & - & - & - & NR & - & - & NR & NR & NR & NR & - \\
\hline D-Glucose & - & + & - & + & + & - & + & + & NR & NR & + \\
\hline Fructose & - & + & - & - & - & - & + & + & + & + & - \\
\hline Mannitol & - & \pm & - & - & + & + & + & + & NR & + & + \\
\hline Sorbitol & - & \pm & - & - & - & + & + & + & + & + & + \\
\hline Glycerol & - & - & $(+)$ & - & - & + & + & + & + & + & - \\
\hline Methanol & - & - & - & - & - & - & - & - & NR & \pm & - \\
\hline Ethanol & - & - & - & - & - & - & - & NR & + & + & - \\
\hline Propanol & - & + & - & - & + & - & NR & NR & - & $\mathrm{NR}$ & - \\
\hline
\end{tabular}


Table 1. cont.

${ }^{*} \mathrm{C}$, Chains; O, ovoid; R, rod-shaped; s, spherical.

$\dagger_{\mathrm{GB}}$, Greenish brown; OB, orange-brown; YB, yellowish brown.

$\ddagger$ L, Lamellar; V, vesicular.

$\$$ Data for salt tolerance of Rba. capsulatus from Hiraishi et al. (1996).

IIOptimal growth occurs in the absence of $\mathrm{NaCl}$, but able to grow in $5 \% \mathrm{NaCl}$.

SOptimal growth occurs in the absence of $\mathrm{NaCl}$, but able to grow in $3 \% \mathrm{NaCl}$.

$\# \mathrm{~b}$, Biotin; $\mathrm{B}_{12}$, vitamin $\mathrm{B}_{12} ; \mathrm{n}$, niacin; $p$ - $\mathrm{ABA}$, $p$-aminobenzoic acid; $\mathrm{t}$, thiamine; $(\mathrm{b}, \mathrm{n})$, a few strains require biotin and/or niacin.

using the program CLUSTAL_X (Thompson et al., 1997) and the alignment was corrected manually. The dendrogram was constructed using the program PHYML (Guindon et al., 2005) using 100 replicates of non-parametric bootstrap analysis, the GTR model of nucleotide substitution and four substitution rate categories.

The sample that yielded strain $\mathrm{JA}^{2} 96^{\mathrm{T}}$ had a $\mathrm{pH}$ of 7.2 , salinity of $1-2 \%$ and temperature of $28-30{ }^{\circ} \mathrm{C}$. Cells of strain JA296 ${ }^{\mathrm{T}}$ were ovoid to rod-shaped, $0.7-1.0 \mu \mathrm{m}$ wide and $1.5-2.0 \mu \mathrm{m}$ long, were motile, multiplied by binary fission and formed chains of four to eight cells. Electron micrographs of ultrathin sections of the cells revealed vesicular internal membrane structures (see Supplementary Fig. S1, available in IJSEM Online). Strain JA296 ${ }^{\mathrm{T}}$ was able to grow photo-organoheterotrophically [anaerobically, in the light $(2400 \mathrm{~lx})$ and in the presence of pyruvate $(0.3 \%$, $\mathrm{w} / \mathrm{v})$ ] and chemo-organoheterotrophically [aerobically, in the dark and in the presence of pyruvate $(0.3 \%$, w/v)]. Photolithoautotrophic growth [anaerobically, in the light (2400 lx), with $\mathrm{Na}_{2} \mathrm{~S} .9 \mathrm{H}_{2} \mathrm{O}(0.5 \mathrm{mM}) / \mathrm{Na}_{2} \mathrm{~S}_{2} \mathrm{O}_{3}(2 \mathrm{mM}) /$ $\mathrm{S}^{0}(0.05 \%, \mathrm{w} / \mathrm{v}) / \mathrm{H}_{2}(20 \%, \mathrm{v} / \mathrm{v})$ and $\mathrm{NaHCO}_{3}(0.1 \%$, $\mathrm{w} / \mathrm{v})$ ], chemolithoautotrophic growth [aerobically, in the dark, with $\mathrm{Na}_{2} \mathrm{~S}_{2} \mathrm{O}_{3}(0.5 \mathrm{mM})$ and $\mathrm{NaHCO}_{3}(0.1 \%$, w/v)] and fermentative growth [anaerobically, in the dark, with pyruvate $(0.3 \%$, w/v)] could not be demonstrated. Substrates that were utilized as carbon sources and electron donors under photo-organoheterotrophic conditions included pyruvate and lactate (Table 1). Those that could not be utilized included formate, acetate, fumarate, malate, glycerol, valerate, caproate, propionate, butyrate, caprylate, gluconate, succinate, aspartate, ascorbate, benzoate, glutamate, propanol, glucose, fructose, mannitol, peptone, sucrose, Casamino acids, sorbitol, ethanol, tartrate, citrate, oxaloacetate, $\alpha$-ketoglutarate, lactose, maltose, starch, pelargonate, arginine, yeast extract and oleic acid. Ammonium chloride, glutamine and molecular nitrogen were utilized as nitrogen sources, whereas urea, glutamate, aspartate, nitrate and nitrite did not support growth. Magnesium sulfate, thiosulfate, cysteine, thioglycolate and sulfide were utilized as sulfur sources, whereas elemental sulfur, methionine and sulfite did not support growth. $\mathrm{NaCl}$ was not obligatory for growth of strain JA296 ${ }^{\mathrm{T}}$, but it tolerated up to $2 \%(\mathrm{w} / \mathrm{v}) \mathrm{NaCl}$. Strain $\mathrm{JA}^{2}{ }^{\mathrm{T}}{ }^{\mathrm{T}}$ grew at $\mathrm{pH}$ 6.0-8.5 (optimum at $\mathrm{pH} 7.0$ ) and $25-35{ }^{\circ} \mathrm{C}$ (optimum at $30^{\circ} \mathrm{C}$ ). Thiamine was required as a growth factor. The colour of the phototrophic culture was yellowish green, turning to reddish brown when exposed to air. The in vivo absorption spectrum of intact cells in sucrose exhibited maxima at 377, 476, 509, 590, 655 and $854 \mathrm{~nm}$, thus

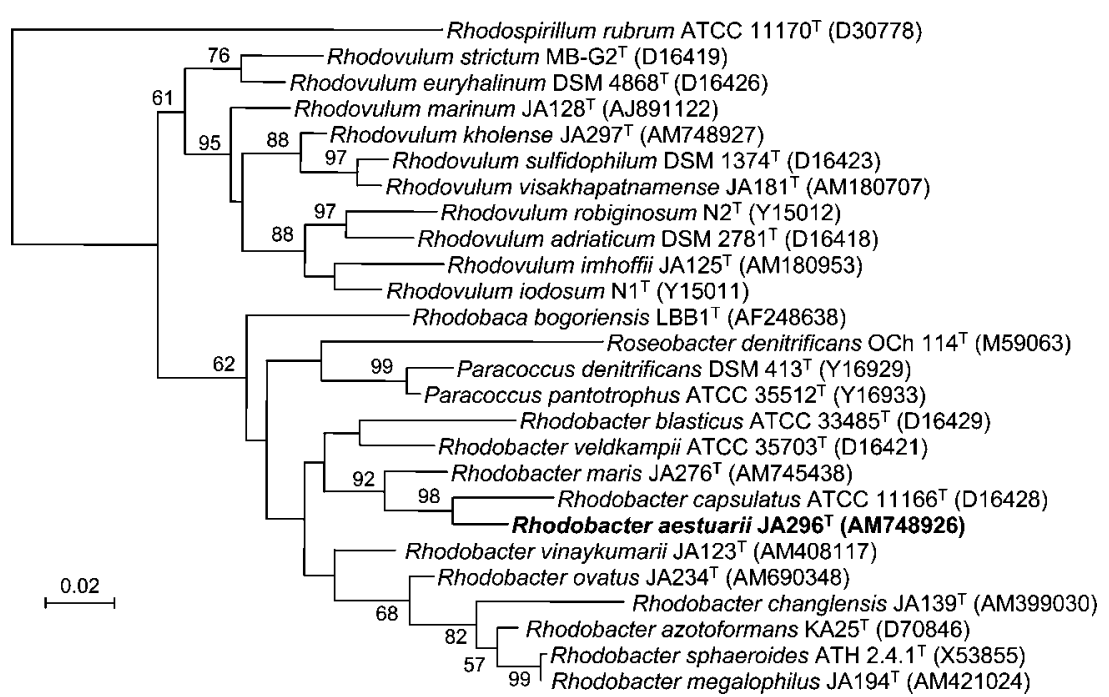

Fig. 1. Evolutionary-distance dendrogram depicting the phylogenetic relationships of strain JA296 ${ }^{\top}$ within the family Rhodobacteraceae, determined using 16S rRNA gene sequence analysis. The phylogenetic tree was constructed by using the PHYML method and was rooted with Rhodospirillum rubrum ATCC $11170^{\top}$ as the outgroup. Numbers at nodes represent bootstrap values (based on 100 resamplings). GenBank accession numbers are shown in parentheses. Bar, 2 substitutions per 100 nucleotide positions. 
confirming the presence of bacteriochlorophyll a (Supplementary Fig. S2a). The absorption spectrum for pigments extracted with acetone (Supplementary Fig. S2b) gave maxima at 431,455 and $488 \mathrm{~nm}$, indicating the presence of the carotenoids spheroidene and spheroidenone. Whole-cell fatty acid analysis of strain JA296 revealed the predominance of $\mathrm{C}_{18: 1} \omega 7 c(62.2 \%)$ with smaller amounts of $\mathrm{C}_{18: 0} 2-\mathrm{OH}(2.5 \%), \mathrm{C}_{18: 0}(7.2 \%)$, $\mathrm{C}_{16: 0}(4.5 \%)$ and $\mathrm{C}_{10: 0} 3-\mathrm{OH}(2.3 \%)$.

The DNA G + C content of strain JA296 ${ }^{\mathrm{T}}$ was $65.1 \mathrm{~mol} \%$ (by HPLC). The phylogenetic relationship of strain JA296 ${ }^{\mathrm{T}}$ to other purple non-sulfur bacteria was examined by $16 \mathrm{~S}$ rRNA gene sequence analysis. The data obtained revealed that the novel isolate branched separately, but clustered with type strains of species of the genus Rhodobacter and was distinct from other genera of purple non-sulfur bacteria (Fig. 1). The highest sequence similarities of strain JA296 ${ }^{\mathrm{T}}$ were found with the type strains of Rhodobacter capsulatus (95.5\%), Rba. maris (94.6\%), Rba. veldkampii (91.6\%), Rba. vinaykumarii (91.0\%), Rba. ovatus (89.8\%), Rba. blasticus $(89.2 \%)$, Rba. azotoformans $(88.5 \%), R b a$. megalophilus (87.8\%), Rba. sphaeroides (87.7\%) and Rba. changlensis $(85.4 \%)$. In addition to $16 \mathrm{~S}$ rRNA gene sequence dissimilarity, strain JA296 ${ }^{\mathrm{T}}$ showed clear phenotypic differences (slime production, vitamin requirement, DNA $\mathrm{G}+\mathrm{C}$ content, carbon and electron donor utilization) from its closest relative Rba. capsulatus (Table 1), thus justifying the description of this strain as a representative of a novel species of the genus Rhodobacter.

\section{Description of Rhodobacter aestuarii sp. nov.}

Rhodobacter aestuarii (aes.tu.a'ri.i. L. gen. n. aestuarii of the estuary, the environment from which the type strain was isolated).

Cells are ovoid to rod-shaped, $0.7-1.0 \mu \mathrm{m}$ wide and 1.5$2.0 \mu \mathrm{m}$ long, are motile, divide by binary fission and form chains of four to eight cells. Growth occurs under anaerobic conditions in the light (photo-organoheterotrophy) or under aerobic conditions in the dark (chemoorganoheterotrophy). Internal photosynthetic membranes are of the vesicular type. The colour of phototrophic cultures is yellowish green. Bacteriochlorophyll $a$ and the carotenoids spheroidene and spheroidenone are present. Substrates that are utilized as carbon sources and electron donors under photo-organoheterotrophic conditions include pyruvate and lactate. $\mathrm{NaCl}$ is not required for growth, but is tolerated up to $2 \%(\mathrm{w} / \mathrm{v})$. Grows at $\mathrm{pH} 6.0$ 8.5 (optimum at $\mathrm{pH} 7.0$ ) and $25-35{ }^{\circ} \mathrm{C}$ (optimum at $\left.30{ }^{\circ} \mathrm{C}\right)$. Thiamine is required as growth factor. $\mathrm{C}_{18: 1} \omega 7 c$ is the dominant fatty acid; small amounts of $\mathrm{C}_{18: 0} 2-\mathrm{OH}$, $\mathrm{C}_{18: 0}, \quad \mathrm{C}_{16: 0}$ and $\mathrm{C}_{10: 0} \quad 3-\mathrm{OH}$ are also found. Photolithoautotrophy, chemolithoautotrophy and fermentative growth have not been demonstrated.
The type strain is $\mathrm{JA}^{2} 26^{\mathrm{T}}\left(=\mathrm{JCM} 14887^{\mathrm{T}}=\mathrm{CCUG}\right.$ $55130^{\mathrm{T}}$ ), isolated from a brown-coloured microbial mat from brackish water of Bhitarkanika mangrove forest, Dangmal, Orissa, India. The DNA G $+\mathrm{C}$ content of the type strain is $65.1 \mathrm{~mol} \%$ (by HPLC).

\section{Acknowledgements}

P.A.K. and T. N. R.S. acknowledge the CSIR (Government of India) for the award of SR fellowships.

\section{References}

Anil Kumar, P., Srinivas, T. N. R., Sasikala, Ch. \& Ramana, Ch. V. (2007). Rhodobacter changlensis sp. nov., a psychrotolerant, phototrophic alphaproteobacterium from the Himalayas of India. Int J Syst Evol Microbiol 57, 2568-2571.

Arunasri, K., Venkata Ramana, V., Spröer, C., Sasikala, Ch. \& Ramana, Ch. V. (2008). Rhodobacter megalophilus sp. nov., a phototroph from the Indian Himalayas possessing a wide temperature range for growth. Int J Syst Evol Microbiol 58, 1792-1796.

Guindon, S., Lethiec, F., Duroux, P. \& Gascuel, O. (2005). PHYML Online - a web server for fast maximum likelihood-based phylogenetic inference. Nucleic Acids Res 33, W557-W559.

Hansen, T. A. \& Imhoff, J. F. (1985). Rhodobacter veldkampii, a new species of phototrophic purple nonsulfur bacteria. Int J Syst Bacteriol 35, 115-116.

Hiraishi, A., Muramatsu, K. \& Ueda, Y. (1996). Molecular genetic analyses of Rhodobacter azotoformans sp. nov. and related species of phototrophic bacteria. Syst Appl Microbiol 19, 168-177.

Imhoff, J. F. (2005). Genus Rhodobacter Imhoff, Trüper and Pfennig $1984,342{ }^{\mathrm{VP}}$. In Bergey's Manual of Systematic Bacteriology, 2nd edn, vol. 2, part C, pp. 161-167. Edited by D. J. Brenner, N. R. Krieg, J. T. Staley \& G. M. Garrity. New York: Springer.

Sasser, M. (1990). Identification of bacteria by gas chromatography of cellular fatty acids, MIDI Technical Note 101. Newark, DE: MIDI Inc.

Srinivas, T. N. R., Anil Kumar, P., Sasikala, Ch. \& Ramana, Ch. V. (2007a). Rhodovulum imhoffii sp. nov. Int J Syst Evol Microbiol 57, 228-232.

Srinivas, T. N. R., Anil Kumar, P., Sasikala, Ch., Ramana, Ch. V. \& Imhoff, J. F. (2007b). Rhodobacter vinaykumarii sp. nov., a marine phototrophic alphaproteobacterium from tidal waters, and emended description of the genus Rhodobacter. Int J Syst Evol Microbiol 57, 1984-1987.

Srinivas, T. N. R., Anil Kumar, P., Sasikala, Ch., Spröer, C. \& Ramana, Ch. V. (2008). Rhodobacter ovatus sp. nov., a phototrophic alphaproteobacterium isolated from a polluted pond. Int J Syst Evol Microbiol 58, 1379-1383.

Thompson, J. D., Gibson, T. J., Plewniak, F., Jeanmougin, F. \& Higgins, D. G. (1997). The CLUSTAL_X windows interface: flexible strategies for multiple sequence alignment aided by quality analysis tools. Nucleic Acids Res 25, 4876-4882.

Venkata Ramana, V., Sasikala, Ch. \& Ramana, Ch. V. (2008). Rhodobacter maris sp. nov., a phototrophic alphaproteobacterium isolated from a marine habitat of India. Int J Syst Evol Microbiol 58, $1719-1722$. 